\title{
PENGARUH PEMBERIAN EKSTRAK RUMPUT KEBAR (Biophytum petersianum Klotzsch) TERHADAP JUMLAH SEL SERTOLI MENCIT (Mus musculus) YANG DIPAPAR 2,3,7,8-TETRACHLORODIBENZO-P-DIOXIN
}

\section{THE EFFECT OF KEBAR GRASS EXTRACT (Biophytum Petersianum Klotzsch) ON AMOUNT OF SERTOLI CELL IN MICE (Mus musculus) EXPOSED BY 2,3,7,8-Tetrachlorodibenzo-p-dioxin}

\author{
Cyrcilia Relita Berlina 1), Hana Eliyani 2), Abdul Samik 2), Widjiati 2), \\ Sri Mulyati 2), Chairul Anwar 2) \\ 1) Mahasiswa, 2) Dosen \\ Fakultas Kedokteran Hewan Universitas Airlangga \\ Kampus C UNAIR, Jl. Mulyorejo-Surabaya 60115 \\ Telp. 031-5992785, Fax. 031-5993015 \\ Email: jbmvunair@gmail.com
}

\begin{abstract}
This study was aimed to know the effect of Kebar grass extract on amount of mice Sertoli cell exposed by TCDD. This study was experimental study with completely randomized design. Thirty adult male mice of Mus musculus strain Balb/C, age 11 weeks and weight 25 - $30 \sim$ were used. Mice were divided into five groups, that were: $\mathrm{K}$ - was control (aquadest 0) $\mathrm{mL}$ ); $\mathrm{K}+$ was injected with TCDD at dose of $7 \mu \mathrm{g} / \mathrm{kg} \mathrm{BW}$; $\mathrm{Pl}$ was injected with TCCD and administrated with Kebar extract $(0,045 \mathrm{mg} / \mathrm{g}$ BW/day); P2 was injected with TCCD and administrated with Kebar extract (0,080 $\mathrm{mg} / \mathrm{g}$ BW/day); P3 was injected with TCDD and administrated with Kebar extract $(0,135 \mathrm{mg} / \mathrm{g} \mathrm{BW} /$ day). Kebar grass extract was administrated in 53 days. Mice were sacrificed and right testis organs were taken. Then, histology preparat with HE staining were made and Sertoli cells were counted. Data were analyzed by One Way ANOV A followed by Duncan test $(\mathrm{a}=0,05)$. The result of this study showed that administration of Kebar grass extract affected amount of mice sertoli cells. $K+(2,92 a \pm 0,109)$ showed significance difference $(\mathrm{p}<0,05)$ compared to Pl $(5,00 \mathrm{~b} \pm 0,374), \mathrm{P} 2(7,64 \mathrm{c} \pm 0,409)$ and P3 $(9,68 \mathrm{c} \pm 0,363)$. Meanwhile, amount of Sertoli cells of P3 at the highest dose did not show significance difference $(p>0,05)$ with K- $(10,16 \llbracket \pm 0,829)$. The conclusion of this study was administration of Kebar grass extract per oral in 53 days could maintain amount of mice Sertoli cell exposed by TCDD.
\end{abstract}

Key words: Kebar grass extract, sertoli cells, 2,3,7,8-Tetraclorodibenzo-p-dioxin

\section{PENDAHULUAN}

Lingkungan hidup merupakan sumber penting dalam menjamin kelangsungan dan kelestarian hidup manusia dan organisme lainnya di muka bumi. Semakin hari dari waktu ke waktu terjadi pencemaran dan perusakan lingkungan yang dilakukan oleh manusia melalui aktivitas-aktivitas yang secara tidak langsung menimbulkan dampak yang besar bagi kesehatan dan kelangsungan hidup manusia serta makhluk hidup lainnya. Hal ini mengakibatkan penurunan kualitas lingkungan hidup. Pencemaran lingkungan dari kelompok senyawa organik persisten (Persistent Organic Pollution (POPs)) dapat menyebabkan polusi lingkungan serta masalah kesehatan pada manusia maupun hewan (Dobrzynski et al., 2009). 2,3,7,8 - Tetrachlorodibenzo-p-dioxin (TCDD) atau sering juga disebut dioxin merupakan salah satu pencemar 
lingkungan tersebut. Dioxin termasuk kelompok kontaminan lingkungan yang terutama dihasilkan melalui proses industri seperti daur ulang elektronik, pembangkit listrik serta pembuatan herbisida dan pestisida (Procopec et al., 2013). Dioxin dianggap sebagai pencemar lingkungan yang paling berbahaya, tersebar luas, persisten dan sangat beracun (Ciftci et al., 2010).

2,3,7,8 - Tetrachlorodibenzo-p-dioxin (TCDD) atau dioxin ini terbukti memiliki efek toksik pada sistem reproduksi. Paparan dioxin memberikan dampak negatif terhadap organ reproduksi jantan antara lain berkurangnya ukuran testis, kelenjar prostat, vesikula seminalis, penurunan jumlah spermatozoa dan peningkatan jumlah spermatozoa yang tidak normal (Latchoumycandane et al., 2003), menurunkan testosteron serum dan hormon reproduksi yaitu GnRH, FSH, LH, serta merusak struktur testis (Yin et al., 2012).

Sel sertoli merupakan salah satu sel penting dalam organ reproduksi jantan yang memiliki fungsi penyokong dan pemberi nutrisi bagi spermatozoa yang berkembang serta penghasil hormon Androgen Binding Protein (ABP) (Junquiera et al,. 2007). Menurut Sudomo dan Tamtono (1979), terganggunya sel Sertoli dapat mengakibatkan terjadinya degenerasi sel-sel spermatogenik dikarenakan kekurangan nutrisi yang didapatkan dari sel Sertoli.

Menurut Maritim et al. (2003), antioksidan adalah zat alami yang merombak radikal bebas dan mencegah efek merusak tubuh. Antioksidan pada tanaman pangan sangat penting karena aktivitasnya dalam menghambat reaksi radikal bebas sehingga melindungi tubuh dari kerusakan oleh Reactive Oxygen Species (ROS) (Yang et al., 2006).

Rumput kebar mengandung vitamin $\mathrm{E}$ dan flavonoid yang dikenal sebagai salah satu antioksidan yang mampu menangkal radikal bebas penyebab kerusakan pada jaringan tubuh. Terdapat efek sinergi antara vitamin $E$ dan flavonoid yang memperkuat kerja keduanya dalam memperbaiki gangguan infertilitas sebagai antioksidan fenolik sehingga mampu menghentikan reaksi berantai peroksidasi lipid asam lemak tidak jenuh pada fosfolipid membran sel testis, membantu mencegah akumulasi radikal bebas pada jaringan - jaringan yang memproduksi spermotozoa, serta melindungi fungsi spermatozoa (Astuti dkk., 2008).

Penelitian ini dilakukan untuk membuktikan pengaruh dari pemberian ekstrak rumput Kebar dengan berbagai dosis terhadap jumlah sel Sertoli mencit (Mus musculus) yang dipapar 2,3,7,8tetrachlorodibenzo-p-dioxin (TCDD).

\section{MATERI DAN METODE}

Sampel yang digunakan dalam penelitian ini adalah testis mencit jantan berjumlah 30 ekor, berumur 11 minggu dan memiliki berat badan antara $25-30$ gram. Bahan yang digunakan dalam penelitian ini adalah ekstrak rumput kebar (Biophytum petersianum Klotzch) dengan tiga dosis yaitu $(0,045 \mathrm{mg} / \mathrm{g}$ $\mathrm{BB} /$ hari, 0,08 mg/g BB/ hari), 0,135 $\mathrm{mg} / \mathrm{g}$ BB/ hari), larutan 2,3,7,8tetrachlorodibenzo-p-dioxin (TCDD), corn oil, Buffer Neutral Formalin 10\%, larutan alkohol konsentrasi 70\%, 80\%, 90\%, 95\% dan alkohol absolut, larutan xylol, parafin cair, dan pewarna Hematoxylin Eosin. Alat yang digunakan untuk menakar dosis yaitu mikropipet, timbangan digital kecil, botol kaca steril dan mikrotube. Peralatan untuk perlakuan menggunakan alat sonde, spuilt 1cc tuberculine. Prosedur terminasi menggunakan alat bedah minor yang terdiri dari hand gloves, masker, pinset, skalpel, gunting dan botol pot kecil. Peralatan untuk pembuatan preparat histologi object glass, cover glass, pipet, tissue processor automatic, water bath, hot plate, 
microtome, dan blade serta alat untuk pemeriksaan histologi dengan menggunakan mikroskop.

Kelompok perlakuan pada penelitian ini terdiri atas lima kelompok yaitu K- (sonde aquadest), $\mathrm{K}+$ (injeksi TCDD dosis $7 \mu \mathrm{g} / \mathrm{kg}$ BB single dose), P1 (injeksi TCDD + sonde ekstrak rumput Kebar dosis 0,045 mg/g BB/ hari), P2 (injeksi TCDD + sonde ekstrak rumput Kebar dosis 0,080 mg/g BB/ hari), dan P3 (injeksi TCDD + sonde ekstrak rumput Kebar dosis 0,135 mg/g BB/ hari) dengan masa perlakuan selama 53 hari sesuai dengan satu setengah siklus spermatogenesis agar dapat dilihat pengaruhnya.

Data kuantitatif sel Sertoli testis diamati dan dihitung dalam 5 lapang pandang pada satu preparat. Penghitungan dilakukan dengan menggunakan mikroskop cahaya dengan perbesaran 400x kemudian dihitung menggunakan aplikasi image raster. Hasil penghitungan tiap lapang pandang dalam satu preparat dijumlahkan kemudian dihitung rataratanya. Analisis data yang diperoleh menggunakan uji ANOVA dan dilanjutkan dengan uji Duncan menggunakan program SPSS 23.0.

\section{HASIL DAN PEMBAHASAN}

Penghitungan jumlah sel Sertoli dilakukan pada seluruh preparat secara mikroskopis. Masing-masing preparat diamati dalam 5 lapang pandang secara acak dan pada masing-masing lapang pandang dilakukan penghitungan sel Sertoli pada 5 tubulus seminiferus.

Hasil penghitungan sel Sertoli yang didapat berupa data kuantitatif yang disajikan dalam Tabel 4.1

Tabel 4.1 Jumlah sel Sertoli di tubulus seminiferus testis mencit (Mus musculus) pada lima kelompok perlakuan yang berbeda setelah pemberian TCDD dan ekstrak rumput Kebar.

\begin{tabular}{|c|c|}
\hline Kelompok Perlakuan & Mean \pm SD \\
\hline K- (Kontrol negatif) & $10,16^{\mathrm{d}} \pm 0,829$ \\
\hline $\begin{array}{l}\mathrm{K}+(\mathrm{TCDD} 7 \mu \mathrm{g} / \mathrm{kg} \\
\mathrm{BB} \text { single dose })\end{array}$ & $2,92^{\mathrm{a}} \pm 0,109$ \\
\hline $\begin{array}{l}\text { P1 (TCDD + Rumput } \\
\text { Kebar 0,045 mg/g BB/ } \\
\text { hari) }\end{array}$ & $5,00 \mathrm{~b} \pm 0,374$ \\
\hline $\begin{array}{l}\text { P2 (TCDD + Rumput } \\
\text { Kebar 0,080 mg/g BB/ } \\
\text { hari) }\end{array}$ & $7,64^{\mathrm{C}} \pm 0,409$ \\
\hline $\begin{array}{l}\text { P3 (TCDD + Rumput } \\
\text { Kebar 0,135 mg/g BB/ } \\
\text { hari) }\end{array}$ & $9,68 d \pm 0,363$ \\
\hline
\end{tabular}

Keterangan: Superskrip (a, b, c, d) yang berbeda pada kolom yang sama menunjukkan adanya perbedaan yang nyata antar perlakuan $(\mathrm{p}<0,05)$.

Perbedaan rerata jumlah hitung sel Sertoli pada masingmasing perlakuan dapat dilihat pada diagram batang 4.1.

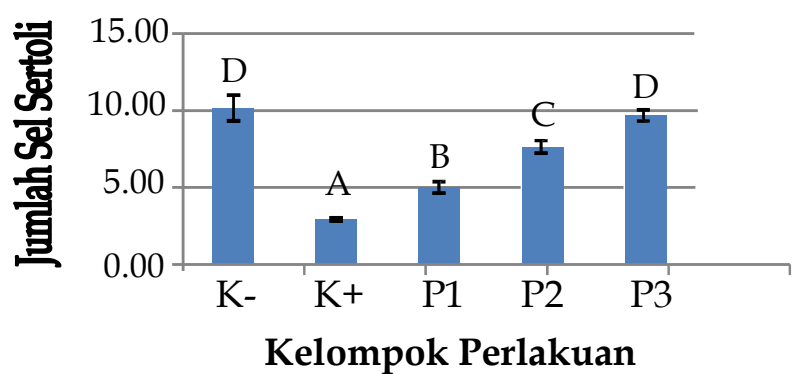

Gambar 4.1 Diagram batang rerata jumlah hitung sel Sertoli di tubulus seminiferus testis mencit (Mus musculus) pada lima kelompok perlakuan yang berbeda.

Pada hasil pengamatan terhadap jumlah sel Sertoli yang terpapar dioxin melalui preparat histopatologi testis mencit menggunakan mikroskop dengan perbesaran 400x menunjukkan adanya penurunan yang signifikan terhadap jumlah sel Sertoli pada kelompok kontrol positif. Perlakuan ini adalah kelompok perlakuan penelitian yang diberi dioxin dengan dosis $7 \mu \mathrm{g} / \mathrm{kg}$ BB single dose tanpa 
pemberian ekstrak rumput Kebar. Hal ini dapat diketahui dengan membandingkan pada kelompok kontrol negatif, dapat dilihat pada gambar 4.2 dan 4.3 .

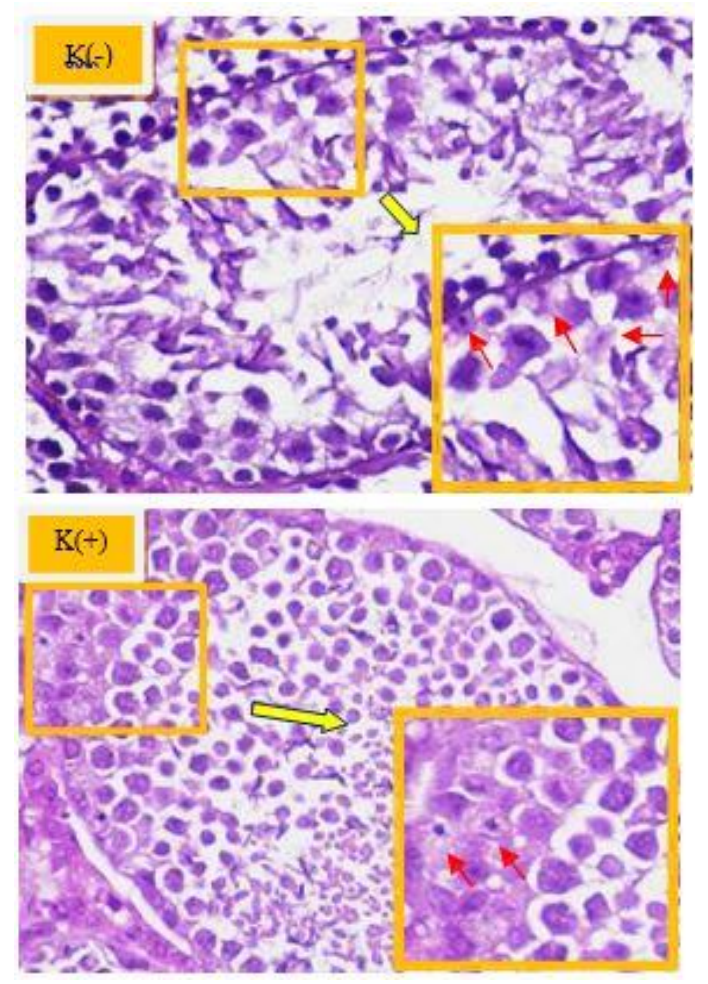

Gambar 4.2 dan 4.3 Gambaran Histopatologi Sel Sertoli Kontrol Negatif (K-) dan Kontrol Positif (K+). (Pewarnaan HE serta perbesaran 400x). Tanda panah menunjukkan sel inti Sertoli.

Setelah dioxin memasuki tubuh, selanjutnya akan berikatan dengan protein yang ada pada sel yang disebut reseptor $\mathrm{Ah}(\mathrm{AhR})$ membentuk senyawa kompleks bersama translocating protein. Senyawa kompleks ini kemudian akan masuk ke dalam inti sel (nucleus), dan berikatan dengan DNA (Deoxyribo Nucleic Acid) pada tempat yang spesif dan diikuti dengan translokasi m-RNA (messenger Ribose Nucleic Acid). Senyawa kompleks ini akan mempengaruhi gengen lain, salah satunya gen spesifik P4501A1 dan menghasilkan produk berupa radikal bebas (ROS) (Warlina, 2009). radikal bebas (ROS) dapat merusak membran sel melalui peroksidasi lipid. Telah diketahui bahwa membran sel terdiri dari lipid bilayer yang merupakan struktur pembangun sel. Peningkatan peroksidasi lipid pada membran sel dapat mengakibatkan terjadinya gangguan transport ion-ion esensial dari luar dan dalam sel. Radikal bebas (ROS) dapat menyebabkan peroksidasi lipid pada semua sel, termasuk sel Sertoli testis (Wati dkk., 2014).

Sel Sertoli pada mencit berperan penting dalam diferensiasi dan perkembangan fungsi testis. Jumlah sel Sertoli pada testis secara pasti menentukan ukuran testis dan produksi spermatozoa sehingga kerusakan atau penurunan jumlah sel Sertoli otomatis akan menurunkan produksi spermatozoa dan meningkatkan jumlah spermatozoa abnormal yang mengakibatkan infertilitas (Schulz et al., 2005). Folicle Stimulating Hormone (FSH) mengawali proses proliferasi spermatogenesis, kemudian testosteron berdifusi dari sel interstitial yang diperlukan untuk pematangan akhir spermatozoa (Agarwal et al., 2003). Berdasarkan Mocarelli et al. (2008), paparan dioxin dapat menghambat pembentukan FSH. Terhambatnya pembentukan FSH mengakibatkan terganggunya spermatogenesis serta menyebabkan turunnya jumlah sel Sertoli (Guyton dan Hall, 2008).

Menurut Boekelheide et al. (2000), terjadinya penurunan jumlah sel Sertoli mengindikasikan kegagalan fungsi sel Sertoli melindungi sel-sel germinal terhadap apoptosis. Kerusakan sel Sertoli akan mengganggu proses spermatogenesis. Lebih lanjut Lohiya et al. (2002), menyatakan jika fungsi sel Sertoli terganggu, maka sekresi ABP, suplai nutrisi, faktor pertumbuhan, laktat dan transferin juga terganggu karena zat-zat tersebut sangat dibutuhkan dalam proses spermatogenesis. Selain itu, terjadinya penurunan jumlah sel Sertoli pada tubulus seminiferus testis mencit setelah 
pemberian dioxin juga mengakibatkan terjadinya peningkatan produksi radikal bebas, sehingga terjadi reaksi peroksidasi lipid yang berlebihan pada tingkat jaringan sel gonad (testis). Terutama kerusakan pada membran sel epitel germinal tubulus seminiferus dan degenerasi sel testis (Dina dkk., 2017).

Paparan dioxin menyebabkan radikal bebas eksogen yang dapat meningkatkan produksi senyawa oksigen reaktif dalam tubuh. Senyawa oksigen reaktif seperti $\mathrm{O}_{2}, \mathrm{H}_{2} \mathrm{O}_{2}$, dan $\mathrm{OH}$, merupakan mediator yang memegang peranan penting dalam kejadian kerusakan oksidatif pada sel termasuk sel Sertoli (Saito dkk., 2005). Paparan dioxin juga dapat menurunkan secara efektif sistem antioksidan testis, yang mengakibatkan peningkatan peroksidasi lipid yang ditandai dengan peningkatan malondialdehid (MDA) pada testis dan menyebabkan stres oksidatif. Malondialdehid merupakan produk penting peroksidasi lipid dan berhubungan dengan biosintesis lipid melalui kerusakan lipid terutama pada fosfolipid. Peroksida lipid menyebabkan kerusakan pada membran sel, sehingga menimbulkan gangguan pada membran dan organel sel (Zhou dkk., 2011).

Hasil penelitian diketahui bahwa pemberian ekstrak rumput Kebar pada mencit selama 53 hari dengan dosis 0,045 mg/g BB/ hari, 0,080 mg/g BB/ hari dapat menghambat penurunan jumlah sel Sertoli (Tabel 4.1), sedangkan pada perlakuan pemberian ekstrak rumput Kebar dosis tertinggi 0,135 $\mathrm{mg} / \mathrm{g}$ BB/ hari diketahui dapat mempertahankan jumlah sel Sertoli dalam tubulus seminiferus (Gambar 2.4, $2.5,2.6)$. Hal ini menunjukkan bahwa ekstrak rumput Kebar memberikan efek positif terhadap paparan dioxin. Efek menguntungkan dari ekstrak rumput Kebar sebagian besar karena sifat antioksidan yang berperan sebagai pelindung utama terhadap stres oksidatif dan mencegah produksi peroksidasi lipid dengan menghancurkan rantai radikal yang beracun, produk sampingan dari proses metabolisme dalam membran biologis pada testis (Wati dkk., 2014).
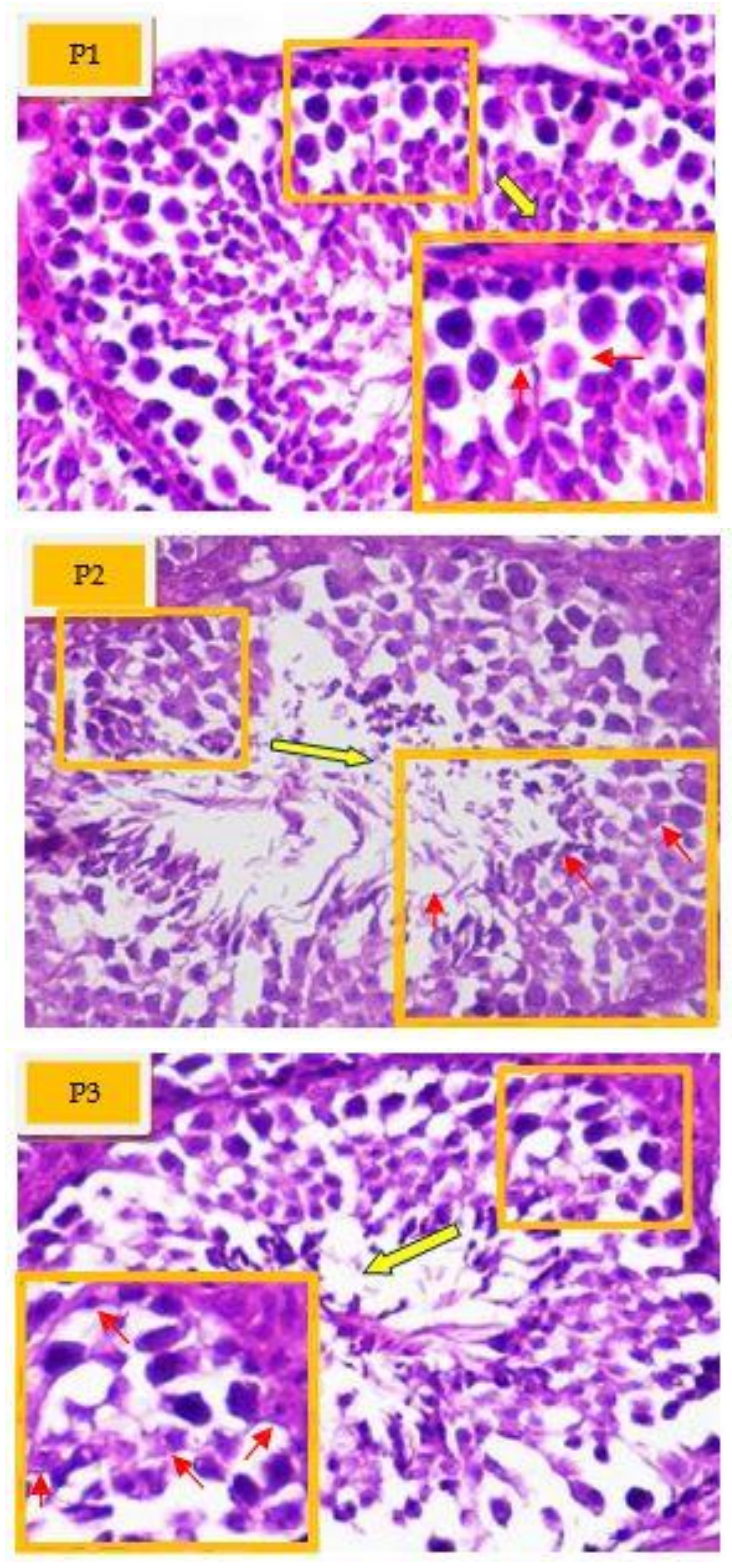

Gambar 2.4, 2.5, 2.6 Gambaran Histopatologi Sel Sertoli Kelompok Perlakuan 1 (P1), Perlakuan 2 (P2) dan Perlakuan 3 (P3). (Pewarnaan HE serta perbesaran 400x). Tanda panah menunjukkan inti sel Sertoli.

Ekstrak Rumput kebar mengandung antioksidan berupa vitamin E dan flavonoid. Vitamin E mempunyai potensi sebagai antioksidan 
pemutus rantai pada membran yang dapat mencegah kerusakan sel oleh peroksidasi lipid dan menghambat pembentukan radikal bebas (Maslachah, 2008). Menurut Halliwel dan Gutteridge (2000) mekanisme kerja antioksidan flavonoid yaitu menekan pembentukan radikal bebas atau ROS dengan cara menghambat enzim, pengkelatan ion logam (metal ion chelating) yang terlibat produksi radikal bebas serta meredam radikal bebas (free radical scavengers). Peroksidasi lipid dapat dicegah pada tahap inisiasi dengan radical scavengers, sementara reaksi propagasi dapat dicegah dengan peroxy-radical scavenger diantaranya dengan antioksidan flavonoid (Widowati, 2005).

Pemberian ekstrak rumput Kebar yang mengandung antioksidan tersebut mampu menangkal radikal bebas dioxin pada sel-sel dan jaringan reproduksi. Ekstrak rumput Kebar diperkirakan dapat menghambat peroksidasi lipid dan memperbaiki membran yang rusak, sehingga dapat mempertahankan jumlah sel Sertoli serta meningkatkan fungsi testis untuk mengontrol biosintesis androgen oleh sel Leydig dan menghasilkan testosteron untuk proses spermatogenesis di epitel tubulus seminiferus. Sintesis testosteron dan spermatogenesis melibatkan kontrol beberapa hormon. GH (Growth Hormone) mempengaruhi secara langsung diferensiasi sel Leydig sebagai tempat sintesis testosteron dan LH mengontrol sintesis testosteron. FSH meningkatkan ABP (Androgen Binding Protein) untuk mengikat testosteron yang kemudian dihantarkan ke tubulus seminiferus sebagai tempat pembentukan spermatozoa, sehingga sel Sertoli dapat berfungsi dengan normal dalam pembentukan membran tubulus seminiferus dan menyediakan lingkungan bagi diferensiasi serta maturasi sel-sel spermatogenik (Mayes 2003).

\section{KESIMPULAN}

Berdasarkan penelitian yang telah dilakukan dapat disimpulkan bahwa pemberian ekstrak rumput Kebar dapat mempertahankan jumlah sel Sertoli tubulus seminiferus testis mencit dari kerusakan akibat paparan 2,3,7,8Tetrachlorodibenzo-p-dioxin (TCDD).

\section{DAFTAR PUSTAKA}

Agarwal, A., R.A. Saleh, and M.A. Bedaiwi. 2003. Role of reactive oxygen species in the pathophysiology of human reproduction. J. Fertil. Steril. 79(4) :829-843

Astuti, S., D. Muchtadi, M. Astawan, B. Purwantara dan T. Wresdiyati. 2008. Pengaruh Pemberian Tepung Kedelai Kaya Isoflavon, Seng (Zn) dan Vitamin E terhadap Kadar Hormon Testosteron Serum dan Jumlah Sel Spermatogenik pada Tubuli Seminiferi Testis Tikus Jantan.

Boekelheide, K., S.L. Fleming, K.J. Johnson, S.R. Patel, and H.A. Schoenfeld. 2000. Role of Sertoli cell in injury-associated testicular germ cell apoptosis. Proc. Soc. Exp. Biol. Med. 255(5): 105-115

Ciftci, O.S. Tanyildizi, and A. Godekmerdan. 2010. Protective effect of curcumin on immune system and body weight gain on rats intoxicated with 2,3,7,8Tetrachlorodibenzo-p-dioxin (TCDD). Immunopharmacology and Immunotoxicology. 23(1): 99-104 
Dina, M.S., Dasrul, Sugito, S. Wahyuni, T. Armansyah TR., dan Ismail. 2017. Penurunan Jumlah Sel Leydig dan Sel Sertoli Tikus Putih (Rattus norvegicus) Strain Wistar Setelah Pemberian Formalin. JIMVET. 01(2): 203-209

Dobrzynski, M.I. Calkosinski, I. Przywitowska, J.K. Brzoza, A.C. waszkiewiez, E, Soltan, and O. Parulska. 2009. Effects of Dioxins in Environmental Pollution on Development of Tooth Disorders. Polish J. of Enfiron. Vol 18(3): 319323

Guyton, A.C. dan J.E. Hall. 2008. Buku Ajar Fisiologi Kedokteran. Edisi ke11. ECG, Penerbit Buku kedokteran. Jakarta.

Halliwell, B and J.M.C. Gutteridge. 2000. Free Radical in Biology and Medicine. Oxford Universiry Press. New York.//https.books.google.co.id. [16 November 2017

Junqueira, L.C., C. Jose, and O.K. Robert. 2007. Histologi Dasar edisi ke-8. Jakarta: EGC. Hal 419432

Latchoumycandane, C., K.C. Chitra, and P.P. Mathur. 2003. 2,3,78Tetrachlorodibenzo-p-dioxin (TCDD) induces oxidative stress in the epididymal sperm of adult rats. Arch Toxicol. 77: 280-284

Lohiya, N.K., B. Manivannan, P.K. Mishra, N. Pathak, S. Sriram, S. Bhande, and S. Panneerdoss. 2002. Chlorofeorm extract of Carica papaya seeds induces long-term reversible azoospermia in langur monkey. Asian. J. Androl. 4(1): 1726
Maritim, A.C., R.A. Sanders, and J. B Watkins III. 2003. Diabetes, Oxidative Stress, and Antioxidants: A Review. J Biochem Molecular Toxycology. 17(1): 24-38

Maslachah, L., R. Sugihartuti, dan R. Kurniasanti. 2008. Hambatan Produksi Reactive Oxygen Species Radikal Superoksida (O2.-) oleh Antioksidan Vitamin E (atocopherol) pada Tikus Putih (Rattus norvegicus) yang Menerima Stressor Renjatan Listrik. Media Kedokteran Hewan. 24(1): 21-26

Mayes, P.A. 2003. Biokimia Harper. Edisi 25. ECG Jakarta.

Mocarelli, P., P.M. Gerthoux, D.G. Patterson Jr., S. Milani, G. Limonta, M. Bertona, S. Signorini, P. Tramacere, L. Colombo, C. Crespi, P. Brambilla, C. Sarto, V. Carreri, E.J. Sampson, W.E. Turner and L.L. Needham. 2008. Dioxin Exposure, from Infancy through Puberty, Produces Endocrine Disruption and Affects Human Semen Quality. Environmental Health Perspectives. 116(1): 70-77

Procopec, D.S., N.B. Buchner, N.S. Fox, L.C. Chong, D.Y.F. Mak, J.D. Watson, A. Petronis, and R. Pohjanvirta, and P.C. Boutros. 2013. Validating reference genes within a mouse model system of 2,3,7,8-tetrachlorodibenzo-pdioxin (TCDD) toxicity. ChemicoBiological Interactions. 205: 63-71

Saito, Y., K. Nishio, Y. Yoshida, and E. Niki. 2005. Cytotoxic effect of formaldehyde with free radicals via increment of cellular reactive oxygen species. Toxycology. 210(23): $235-245$ 
Schulz, R.W., S. Menting, J. Bogerd, L.R. Franca, D.A. Vilela, and H.P. Godinho. 2005. Sertoli cell proliferation in the adult testis evidence from two fish species belonging to different orders. Biol. Reprod. 73(3): 891-898

Sudomo, A dan D.G. Tamtono. 1979. Perubahan Struktur Histologis Testis sesudah Vasektomi. Dalam Hadi, K. (ed): Spermatologi. Perkumpulan Andrologi Indonesia. Surabaya

Yang, R.Y., S.C.S. Tsou, T.C. Lee, W.J. Wu, P.M. Hanson, G. Kuo, L.M. Engle, and P.Y. Lai. 2006. Distribution of 127 edible plant species for antioxidant activities by two assays. Jurnal of the Science of Food and Agriculture. 86:2395-2403

Yin, H.P., J.P. Xu, X.Q. Zou, and Y. Wang. 2012. Effects of vitamin $E$ on reproductive hormones and testis structure in chronic dioxintreated mice. Toxicology and Industrial Health. 152-161
Warlina, L. 2009. Persistent Organic Pollutans (POPs) dan Konvensi Stockholm. Jurnal Matematika, Sains, dan Teknologi, 10(2): 102111

Wati, W.K., Wurlina, dan Sarmanu. 2014. Potensi Vitamin E terhadap Jumlah Sel Spermatogenik pada Mencit yang Terpapar 2,3,78tetrachlorodibenzo-p- dioxin (TCDD). Veterinaria Medika. 7(3): 224-231

Widowati, W., R. Safitri, R. Rumumpuk, M. Siahaan. 2005. Penipisan Aktivitas Superoksida Dismutase pada Berbagai Tanaman. JKM. 5 (1): 33-38

Zhou, D.X.J. Zhang, H.X. Wang, Y. Xue. 2011. ffect of formaldehide exposure on structure and function of epididimis in adult rats: A histological and biochemical study. Toxicol. Environ. Chem. 93: 134-144. 